\title{
Children Among the Natural Hazards and Covid-19 Pandemic in Indonesia
}

\author{
Ina Winangsih ${ }^{1, *}$, Euis Kurniati ${ }^{2}$, Vina Adriany ${ }^{3}$ \\ ${ }^{1,2,3}$ Department of Early Childhood Education, School of Postgraduate, Universitas Pendidikan Indonesia \\ *Corresponding author. Email: ina@upi.edu
}

\begin{abstract}
During the COVID-19 pandemic in Indonesia, something that has escaped the public attention is the high level of natural disaster threats in Indonesia. If this condition is left unattended, the whole situation in Indonesia will become even more complex and will do harm to the children. Through the perspective of post-developmentalism, the researcher believes that children are able to be included in multi-hazards natural disaster risk mitigation. This research uses meta-analysis to examine several research results that identify the children's participation during multi-hazards disasters and pandemic situations. The result finds that even during multi-hazards disasters and pandemic situations, children should be given opportunities to participate in the disaster mitigation as a preventive measure. Therefore, children's resilience would increase and become a reducing factor that may lower the disaster risks in Indonesia.
\end{abstract}

Keywords: Natural disaster, Covid-19 pandemic, children's participations, multi-hazards.

\section{INTRODUCTION}

An early childhood teacher is a formal legal educator When a natural disaster strikes, it sometimes triggers whole new other disasters, such as another natural disaster, disease spreading, or social conflict. Both natural and non-natural disasters triggered by another disaster could raise a more complex risk. It can also increase the level of vulnerability within the society. In this article, the interaction between disasters and its effects will be discussed by using a concept called multihazards [1].

Nowadays, Indonesian children are facing threats which are divided into a natural disaster and a non-natural disaster. These two types of disasters cannot always be predicted. Natural disasters such as tectonic earthquakes may happen at any time, without showing any prior signs. On the other hand, natural disasters such as landslides, floods, and wildfires can be prevented and predicted when prior signs are showing that may lead to the threat itself [2].

Besides the fact mentioned above, a non-natural disaster has been happening since 2020 in Indonesia. It is the COVID-19 pandemic, caused by the spreading of coronavirus between humans. COVID-19, by itself, has caused several changes in public order within Indonesian society. Changes happened including economics, health, food, environment, education, etc [3].

These natural and non-natural disasters occurred throughout Indonesia and mostly occurred in Java island. According to data, the island of Java has the highest population density, where the largest number of people are within the range age of 0-9 years old [4]. Children are one of the groups most vulnerable to this condition and have felt the impact of changes occurred due to the threat of multi-hazards and the COVID-19 pandemic [5], [6].

One of the immediate impacts felt by children is the loss of socialization activities supposed to happen in normal conditions. The closure of schools and playgrounds also requires children to adapt to these forced conditions. This can trigger another set of threats from health, diversion of inappropriate activities, to violence or neglect in family environments [7], [8].

Both the government and the society are very focused on tackling the spread of the coronavirus. There are policies issued to deal with the pandemic in Indonesia. The community has undergone a large-scale social distancing (Pembatasan Sosial Berskala Besar; PSBB) to the new normal transition which requires the implementation of the COVID-19 protocol in each and every place. They are done to suppress the spreading of coronavirus disease and to tackle other impacts that the pandemic will cause. 
The massive tackling of COVID-19 has made the threat of natural disasters seemingly escape the public's attention [9]. Emergency response efforts for natural disasters amidst the pandemic era are a challenge for both the government and the society, especially in the health sector. Up until June 2020, 1,549 natural disasters have occurred, resulting in 198 deaths and 2.3 million displaced and evacuated victims [10]. At the same time, the coronavirus cases are increasing. The areas that become red zones continue to grow. There are even 10 volcanoes at the alert level located in the red zone of COVID-19 [11].

This is a serious matter because natural and nonnatural disasters become a very complex situation when they occur together [12]. Besides the evacuation process, refugee camps and health services become very vulnerable to the spread of the virus [13], [14]. Therefore, the multi-hazards mitigation efforts amidst the pandemic must be organized and prepared with the participation of children, who become one of the groups vulnerable to said condition.

Previous researches show that children's participation can give a positive impact on increasing resilience [15], [16], including disaster mitigations [17], [18]. However, there is not any research that discusses the multi-hazards mitigation amidst the pandemic for children in Indonesia.

This article is made to discuss how children have the capacity to be included in multi-hazards and COVID-19 pandemic mitigation in Indonesia, given that every group within the society must be able to carry out evacuation efforts while also still heeding the COVID-19 protocol. This will become difficult if multi-hazards and pandemic disaster mitigation is not properly addressed and prepared.

\subsection{Post-Developmentalism}

Developmentalism theories that discuss children's cognitive stages have become a view that is implemented in schools or childcare [19], [20]. This perspective should show that through specific stages, children have to be stimulated according to the said stage. However, this sometimes can limit their cognitive potential and limit the children's access to crucial issues around them.

In response to the issue said above, this article will use the perspective of post-developmentalism, where children are seen as active agents and are believed to be able to understand the crucial issues around them [21], [22]. With this view, children are not only seen as the victims, but also as individuals that have the resilience to protect themselves and others [23]. Children are able to understand the issue of disaster mitigation and able to be active agents in both pre and post-disaster stages [24], [25].
When children are seen through the postdevelopmentalism perspective, even though they are included in the groups vulnerable to the condition, children are not only given the aspect of protection, but also on the aspect of participatory [17]. The understanding, experiences, and opinions of the children must also be considered given that the children themselves who will face the said threats.

\section{METHOD}

Using the meta-analysis method, this article identifies the results of previous researches that are inter-related to each other. The analysed researches include multihazards and COVID-19 disasters mitigation [9], [26], COVID-19 pandemic situation on children [27], [28], and researches about children's participations in natural and non-natural disasters mitigations [12], [17], [29], [30], [31], [32].

\section{DISCUSSION}

The result of the analysis shows that there are two themes that are going to be discussed in this article, which are 1) multi-hazards disaster mitigation plan in Indonesia and 2) children's participation in natural and non-natural disasters conditions.

\subsection{Multi-hazards and COVID-19 Disaster Mitigation Plan in Indonesia}

In their research, [12], [26], [33] gave a recommendation to the government to develop a databased multi-hazards disaster mitigation policy plan amidst COVID-19 pandemic. The focus areas are the health system, evacuation system, and budget allocation to increase the community resilience.

In developing the mitigation and contingency plan, the government is supposed to consider the worst case scenario that involves the multisector [5], [34]. The example disasters that can cause another disaster are flood followed by a landslide, earthquakes followed by tsunami or wildfire, and the impacts of spreading diseases in refugee camps [35]. Also, interventions from the psychosocial impact should also be considered and prepared [36].

The effort to minimize disaster risks in Indonesia has been prepared in several sectors [34]. However, the spread of the virus in 2020 can test whether the designed disaster mitigation plan in Indonesia can be integrated with the pandemic conditions [9].

As one of the countries with high population density [4], the Indonesian government should have been aware of the potential for a pandemic in Indonesia. Also, besides the high population density, Indonesia also has a high and active traffic between countries. Also, disaster 
awareness in the Indonesian society is still not comprehensive yet [37]. These situations can increase disaster risks [38]. Health, economic, and education sectors that are very crucial to the community must also be integrated and prioritize in terms of multi-hazards mitigations.

Amidst of the COVID-19 pandemic, Indonesia possesses natural disaster threats such as tornado, flood, and earthquake [39]. Both COVID-19 pandemic and natural disaster can cause a crisis in society. When the two disasters happen at the same time without comprehensive disaster mitigation, the crisis will become even more threatening for the community [1], [12]. Until now, there has been no contingency plan that covers multi-hazards in Indonesia during the COVID-10 pandemic [9].

A scientific model for design disaster mitigation needs to be built [26], such as in [12] that explains the research on the complexities occurred in America during a multi-hazards disaster amidst of COVID-19 pandemic, that developed an multi-risk assessment model, where the complexity of the risk is reduced by increasing the quality of the health system.

Going back to the very important role of government in disaster risk reduction, the development of a disaster mitigation model and a multi-hazards contingency plan during the pandemic should have been well prepared and designed. As this is a very complex situation, all the aspects from several sectors should also be attended to. This can be realized with empirical data and the community involvement, including women and children [40], [41] during its preparation and implementation.

\subsection{Children Participation in Multi-hazards and Pandemic Mitigation}

During the pandemic situation, children gain COVID-19 information massively [42]. Both parents and teachers have their role in relaying the information [43]. They have gained a lot of knowledge regarding how to relay COVID-19 related information to children, from guidelines or infographics provided by the government [44], [45].

With the information, children can show their understanding regarding the threat of COVID-19 pandemic [46]. The situation can be shown by the children's ability to relay information in their community. In addition, children should also be able to follow the COVID-19 health protocol. The children's ability in understanding and implementing the COVID19 health protocol in [47] has proved that children are able to understand threats around them. Even so, children can be the communicator agent in the COVID-19 spreading mitigation.
However, when it refers to the massive implementation in the education sector, information regarding other threats such as a natural disaster threat are seemingly too complex for children to understand. The natural disasters that have never been faced by the children are considered to be an issue that is still kept away from the children. Children are thought to still not understand such abstract things [20].

On the other hand, the government should also build a health system that is both adequate and responds to disasters. The multi-hazards condition requires a country to have a good health system, because this very aspect is what may guarantee the community's safety, especially the children.

When referring to the Sendai Framework of Disaster Risk Reduction [48], the government should strengthen the good governance in preparing disaster mitigation. It may serve as a guidance for when the government needs to prepare and implement the community's participation, issue the appropriate policy, and build an information system to empirically create a policy [49]

In the World Conference of Disaster Risk Reduction (WCDRR) on children participation, shows that children are perfectly able to participate in preparing disaster mitigation plans [29]. Children are able to share their experience and opinion to each other when the said children have been given understandings on disasters. This also supports the research that children participation in disaster mitigation shows a positive impact [17].

Other than being able to understand the threats that they are facing, children would also learn how to behave when the disaster strikes. Data shows that the children's ignorance of disaster issues cause themselves to become a victim. The ignorance also creates a more severe psychological impact because the children only understand a new set of disaster when they actually face it.

This is also supported through data gained from a series of interviews with children who caught the virus during the SARS pandemic [30]. The data shows that the children notice a problem in communication. The children have their fears because they do not understand the condition they are facing. The children also express their anxiety about their soul and their life. This is also explained in [18] that miscommunication can be a stressor agent during pandemic. Therefore, in this situation, a clear information to the children about the threat they are facing right now should be done perfectly.

However, to further involve the children's role in multi-hazards and COVID-19 pandemic disaster mitigation, relaying information is not enough. The actual stages of children participation actually happen when the children are given space to give their opinion and be involved in decision making [50], [51]. Therefore, the government should make a special forum where 
children are facilitated to understand, learn, and voice their opinions, and also to follow up the issue [29]. It can be done in both formal and informal education settings [52].

If children are given a space to involve and participate in disaster mitigation, children will become an active agent in society [53]. When the children become an active agent, children will also be a communicator for their own community. As they grow up, their critical thinking will also develop along with their understanding of the threats in their surroundings [31], [32]. Once it is realized, then the government can increase the resiliency level within the Indonesian society.

\section{CONCLUSION}

Indonesia's readiness in facing multi-hazards conditions can be determined by multisector mitigation planning and is able to involve the role of the community, including the children. When faced with the multi hazards situation during the pandemic, the community and the government will be trapped in a very complex situation if the mitigation plan is not well prepared. The disaster mitigation plan in Indonesia must be created more thoroughly and not only focusing on the natural disaster planning. The evacuation and the readiness and preparedness plans should also consider the pandemic spread protocols.

The result of the discussion shows that the government should start to consider the children's involvement in preparing the disaster mitigation plans. For children, the access to information gained from other people is very important to their lives. A step further than that is that the children's involvement will give a positive impact. Children's resiliency level will increase and the children's role as an active agent can help reduce the disaster risk. The positive influence of children's involvement in disaster mitigation can indicate that it is not impossible for early childhood children to be involved in disaster mitigation. Children have the right to participate and voice their opinion when a policy or a step that is taken by the community will affect their lives.

There have been many guides for parents and teachers to deliver information regarding the COVID-19 pandemic. Campaigns to wear masks, wash hands, and do social distancing have been understood by the children. This can be a great start to give information to children that viruses are not the only threat around them.

If the government and society constantly put an effort to analyse and design a mitigation plan that is proactive, the multi-hazards and pandemic that is happening can be turned into a way to raise resiliency level and reduce disaster risk in Indonesia.

\section{ACKNOWLEDGMENT}

This paper is supported by the General Directorate of Higher Education, Ministry of Education and Culture, Republic of Indonesia.

\section{REFERENCES}

[1] Gill JC, Malamud BD. Hazard interactions and interaction networks (cascades) within multi-hazard methodologies. Earth System Dynamics. 2016;7(3):659-79.

[2] Purwani A, Fridani L, Fahrurrozi F. Pengembangan media grafis untuk meningkatkan siaga bencana banjir. Jurnal Obsesi: Jurnal Pendidikan Anak Usia Dini. 2019;3(1):55-67.

[3] Nasruddin R, Haq I. Pembatasan Sosial Berskala Besar (PSBB) dan masyarakat berpenghasilan rendah. SALAM: Jurnal Sosial dan Budaya Syar-i. 2020;7(7):639-48.

[4] BPS. Jumlah dan distribusi penduduk [Internet]. 2010 [cited 2020 Aug 13]. Available from: https://sp2010.bps.go.id.

[5] Kar N. Psychological impact of disasters on children: Review of assessment and interventions. World Journal of Pediatrics. 2009;5(1):5-11.

[6] UNICEF. COVID-19: Children in Indonesia at risk of lifelong consequences [Internet]. UNICEF. 2020 [cited 2020 Aug 19]. Available from: https://www.unicef.org/indonesia/press-releases/ covid-19-children-indonesia-risk-lifelongconsequences.

[7] Griffith A. Parental burnout and child maltreatment during the COVID-19 Pandemic. Journal of Family Violence. 2020;June:1-7. Available from: https:// link.springer.com/article/10.1007/s10896-02000172-2.

[8] Rundle AG, Park Y, Herbstman JB, Kinsey EW, Wang YC. COVID-19-related school closings and risk of weight gain among children. Obesity. 2020;28(6):1008-9.

[9] Dzakwan MHA. Urgensi pembentukan protokol multi-bencana dalam pandemi COVID-19. CSIS Commentaries. 2020;April:1-11. Available from: https://www.csis.or.id/download/251-post-2020-0422-CSIS_Commentaries_DMRU_056_ID_ Dzakwan.pdf.

[10]Nugrahaeny DE. BNPB: Tantangan masyarakat hadapi bencana bertambah di masa pandemi [Internet]. Jakarta: Kompas.com; 2020 [cited 2020 Aug 18]. Available from: https://nasional .kompas. com/read/2020/07/01/07525201/bnpb-tantanganmasyarakat-hadapi-bencana-bertambah-di-masapandemi?page=all . 
[11]Redi. Virus corona: Banjir dan letusan gunung berapi jadi ancaman nyata di tengah wabah, pemerintah "masih bahas pembicaraan awal" [Internet]. Jakarta: BBC-Indonesia; 2020 [cited 2020 Aug 16]. Available from: https://www.bbc.com/ indonesia/indonesia-52446120.

[12] Hariri-Ardebili MA. Living in a multi-risk chaotic condition: Pandemic, natural hazards and complex emergencies. International Journal of Environmental Research and Public Health. 2020;17(16):1-16.

[13] Attanayake J. The dual risks of natural hazards and COVID-19 [Internet]. PreventionWeb: The knowledge platform for disaster risk reduction. 2020 [cited 2020 Aug 19]. Available from: https://www.preventionweb.net/news/view/71687.

[14]Cahill H, Dadavand B, Shlezinger K, Romei K, Farrelly A. Natural disasters and pandemic: supporting student and teacher wellbeing after a crisis. Melbourne: Youth Research Centre; 2020.

[15] Nicholson J, Kurnik J, Jevgjovikj M, Ufoegbune V. Deconstructing adults' and children's discourse on children's play: Listening to children's voices to destabilise deficit narratives. Early Child Development and Care. 2015;185(10):1569-86.

[16] Rollins N, Lord JP, Walsh E, Weil GR. Some roles children play in their family: Spacegoat, baby, pet, and peacemaker. Journal of the American Academy of Child Psychiatry [Internet]. 1973;12(3):511-30. Available from: http://dx.doi.org/10.1016/S00027138(09)61261-9.

[17]Lopez Y, Hayden J, Cologon K, Hadley F. Child participation and disaster risk reduction. International Journal of Early Years Education. 2012;20(3):300-8

[18] Shaw J, Espinel Z, Shultz J. Children: Stress, trauma and disasters [Internet]. Disaster Life Support Publishing. Tampa; 2007. Available from: http://www.umdeepcenter.org/x466.xml.

[19]Driver R. When is a stage not a stage? A critique of Piaget's theory of cognitive development and its application to science education. Educational Research. 1978;21(1):54-61.

[20]Lefa B. The Piaget theory of cognitive development: An educational implications. Educational Psychology [Internet]. 2014;1(9):1-9. Available from: https://www.researchgate.net/ publication/25 2532772_Constructing_a_theory_of_learner_auton omy_Some_steps_along_the_way.

[21]Burman. Deconstructing developmental psychology. second. Sussex: Routledge; 2008.

[22] Solehuddin M, Adriany V. Kindergarten teachers' understanding on social justice: Stories from Indonesia. SAGE Open. 2017;7(4):1-8. Available from: https://journals.sagepub.com /doi/pdf/10.1177 $/ 2158244017739340$.

[23] Ronan PKR, Haynes K, Amri A, Frontiers R. Childcentred disaster risk reduction: Can disaster resilience programs reduce risk and increase the resilience of children and households? Australian Journal of Emergency Management. 2016;31(3):49 58 .

[24]Gibbs L, Mutch C, O’Connor P, MacDougall C. Research with, by, for, and about children: lessons from disaster contexts. Global Studies of Childhood. 2013;3(2):129-41.

[25] Winangsih I, Kurniati E. Disaster Mitigation in Early Childhood Education. In International Conference on Early Childhood Education and Parenting 2009 (ECEP 2019). 2020;45:296-301.

[26] Quigley MC, Attanayake J, King A, Prideaux F. A multi-hazards earth science perspective on the COVID-19 pandemic: the potential for concurrent and cascading crises. Environment Systems and Decisions [Internet]. 2020;40(2):199-215. Available from: https://doi.org/10.1007/s10669-020-09772-1.

[27] Akseer N, Kandru G, Keats EC, Bhutta ZA. COVID19 pandemic and mitigation strategies: implications for maternal and child health and nutrition. The American Journal of Clinical Nutrition. 2020; 112(2):251-6.

[28] Balasubramanian, Rao NM, Goenka A, Roderick M, Ramanan A V. Coronavirus disease 2019 (COVID19) in Children - What we know so far and what we do not. Indian Pediatrics. 2020;57(5):435-42.

[29]Cumiskey L, Hoang T, Suzuki S, Pettigrew, Herrgård MM. Youth Participation at the Third UN World Conference on Disaster Risk Reduction. International Journal of Disaster Risk Science. 2015;6(2):150-63.

[30] Koller D, Nicholas D, Gearing R, Kalfa O. Paediatric pandemic planning: Children's perspectives and recommendations. Health \& Social Care in the Community. 2010;18(4):369-77.

[31]Masten AS, Motti-Stefanidi F. Multisystem resilience for children and youth in disaster: reflections in the context of COVID-19. Adversity and Resilience Science. 2020;1:95-106.

[32]Peek L. Children and Disasters: Understanding vulnerability, developing capacities, and promoting resilience - An Introduction. Child Youth Environments. 2008;18(1):1-29.

[33] Parvin G, Rahman MH, Ahsan R, Abedin MA. Media discourse about the pandemic novel coronavirus (COVID-19) in East Asia: The Case of China and Japan. Social Sciences \& Humanities Open [internet]. 2020; under-review:1-25. Available 
from https://ssrn.com/abstract=3603875 or http://dx .doi.org/10.2139/ssrn.3603875.

[34] James E. Getting ahead of the next disaster: Recent preparedness efforts in Indonesia. Development in Practice. 2008;18(3):424-9.

[35] Kouadio IK, Aljunid S, Kamigaki T, Hammad K, Oshitani H. Infectious diseases following natural disasters: Prevention and control measures. Expert Review of Anti-Infective Therapy. 2012;10(1):95104.

[36]Elangovan, Kasi. Psychosocial disaster preparedness for school children by teachers. International Journal Of Disaster Risk Reduction [Internet]. 2014;12:11924. Available from: http://dx.doi.org/10.1016/j.ijdrr .2014.12.007.

[37] Sampurno PJ, Sari YA, Wijaya AD. Disaster (STEM-D) education for building students' disaster literacy climate change and STEM education in indonesia view project using technology to develop teaching material based on local potential in learning physics: View Project Pandu Joy and Disaster; 2015. Available from: https://www.researchgate.net/ publication/281775230.

[38] Silva V, Paul N. Potential impact of earthquakes during the 2020 COVID-19 pandemic. Earthquake Spectra. 2020;1-22.

[39] WHO. Preparedness for cyclones, tropical storms, tornadoes,floods and earthquakes during the COVID-19 pandemic. World Health Organ [Internet]; 2020. Available from: https://www.who .int/publications/i/item/WHO-2019-nCoV-

Advisory-Preparedness-2020.1.

[40]Delicado A, Rowland J, Fonseca S, de Almeida AN, Schmidt L, Ribeiro AS. Children in disaster risk reduction in Portugal: Policies, education, and (non) participation. International Journal of Disaster Risk Science. 2017;8(3):246-57.

[41]UNDP. Gender and Disasters. Encyclopedia Environmental Health; 2011. Available from: www.undp.org.

[42] Schaefer MB, Abrams S, Kurpis M, Abrams M, Abrams C. "Making the Unusual Usual:" Students' perspectives and experiences of learning at home during the COVID-19 pandemic. Middle Grades Review [Internet]. 2020;6(2):1-17. Available from: https://scholarworks.uvm.edu/mgreview/vol6/iss2/ 8.

[43] Mudavanhu C, Manyena SB, Collins AE, Bongo P, Mavhura E, Manatsa D. Taking children's voices in disaster risk reduction a step forward. International Journal of Disaster Risk Science. 2015;6(3):267-81.

[44]Ikatan Dokter Anak Indonesia. Panduan klinis tatalaksana COVID-19 pada Anak. Jakarta: IDI;
2020. Available from: https://covid19.idionline .org/wp-content/uploads/2020/04/15.IDAI_.pdf.

[45] Kementerian Kesehatan RI. Panduan pelayanan kesehatan balita pada masa tanggap darurat COVID19. Jakarta: Kementerian Kesehatan RI; 2020;1-30.

[46]Ivari N, Sharma S, Ventä-Olkkonen L. Digital transformation of everyday life - How COVID-19 pandemic transformed the basic education of the young generation and why information management research should care? International Journal of Information Management [Internet]. 2020;55: 102183. Available from: https://doi.org/10.1016/ j.ijinfomgt.2020.102183.

[47] Samuelsson IP, Wagner JT, Ødegaard EE. The coronavirus pandemic and lessons learned in preschools in Norway, Sweden and the United States: OMEP Policy Forum. International Journal of Early Childhood [Internet]. 2020;52(2):129-44. Available from: https://doi.org/10.1007/s13158020-00267-3.

[48]UNDRR. Sendai Framework for Disaster Risk Reduction 2015-2030; 2015. Available from: https://www.undrr.org/.

[49] UNDP. Governance principles, institutional capacity and quality. New York: UNDP; 2011. Available from: https://pfmkin.org/node/277.

[50] Hart R. Children's participation: from Tokenism to Citizenship. Florence: UNICEF; 1992.

[51] Shier H. Pathways to Participation: Openings, opportunities and obligations. Children \& Society. 2001;15(2):107-17.

[52]Hayden J, Petal M. Child-centered risk reduction research into action brief: Early Childhood and Disaster Risk Reduction; 2017.

[53] Yoshikawa H, Wuermli AJ, Britto PR, Dreyer B, Leckman JF, Lye SJ, et al. Effects of the global Coronavirus disease-2019 pandemic on early childhood development: Short and Long term risks and mitigating program and policy actions. The Journal of Pediatrics [Internet]. 2020;223:188-93. Available from: https://doi.org/10.1016/j.jpeds .2020 .05 .020 